\title{
Effect of Elevated Temperature on Development Time of Rice Yellow Stem Borer
}

\author{
N. Manikandan ${ }^{1 *}$, J. S. Kennedy ${ }^{2}$ and V. Geethalakshmi ${ }^{3}$ \\ 'Research Scholar (Agricultural Meteorology), Tamil Nadu Agricultural University, Coimbatore, Tamil Nadu, India; \\ manilakshmi_144@yahoo.com \\ ${ }^{2}$ Professor (Department of Entomology), Tamil Nadu Agricultural University, Coimbatore, Tamil Nadu, India; \\ jskennedy@gmail.com \\ ${ }^{3}$ Professor (Agro Climate Research Centre), Tamil Nadu Agricultural University, Coimbatore, Tamil Nadu, India; \\ geetha@tnau.ac.in
}

\begin{abstract}
Insects, as cold-blooded animals are directly under the control of temperature for their growth and they cannot sustain living below and above certain thresholds. Therefore, temperature is probably the single most important environmental factor influencing insect behavior. Current estimates of changes in climate indicate an increase in global mean annual temperatures of $1^{\circ} \mathrm{C}$ by 2025 and $3^{\circ} \mathrm{C}$ by the end of the next century. Such increases in temperature may decrease the developmental time and increase the number of generations per year. An investigation was adopted to understand the effect of five different constant temperatures $\left(28.3^{\circ} \mathrm{C}, 30.6^{\circ} \mathrm{C}, 32.7^{\circ} \mathrm{C}, 34.3^{\circ} \mathrm{C}\right.$ and $\left.36^{\circ} \mathrm{C}\right)$ on the development time of Yellow Stem Borer (YSB). The results revealed that the number of eggs laid by YSB increased at higher temperatures while egg hatching was reduced. Egg hatching was higher $(90.6 \%)$ in $30.6^{\circ} \mathrm{C}$ followed by $28.3^{\circ} \mathrm{C}$. The development time taken by different stages of the YSB revealed that there was an inverse relationship with development time and incubation temperature level. Insects develop faster which may oviposit early and hence the population was likely to grow earlier than expected.
\end{abstract}

Keywords: Yellow Stem Borer, Temperature, Climate Change, Global Warming.

\section{Introduction}

Crop plants used as food by human beings are damaged by over 10,000 species of insects, and cause an estimated annual loss of $17.5 \%$ in eight major field crops (cotton, rice, maize, sugarcane, rapeseed-mustard, groundnut, pulses, coarse cereals, and wheat) in India [1]. Rice is one of the most important and extensively grown foods in the tropical and subtropical regions of the world. Several improvements have been made to boost up productivity, but insect pests still continue to be major limiting factor [2]. Rice is attacked by more or less 100 species of insect pests of which 20 are of economic importance [3]. The Yellow Stem Borer (YSB) Scirpophaga incertulas Walker (Pyralidae: Lepidoptera) of rice is one of the major pests in all rice growing regions of Asia [4] and in South
East Asian region [5, 6] and India in particular [7]. The occurrence of insect pests in paddy fields is influenced by various factors including meteorological conditions, cultivation methods, and rice variety. Among these meteorological conditions, temperature, is the most important factor.

The habitats and survival strategies of insects are strongly dependent on temperature because they are cold-blooded. Therefore, temperature is probably the most important environmental factor influencing their behavior, distribution, development, survival and reproduction [8]. An analysis conducted [9], indicated that the Earth's climate has warmed by approximately $0.74^{\circ} \mathrm{C}$ and it is also projected to increase by 1.1 to $6.4^{\circ} \mathrm{C}$ at the end of the $21^{\text {st }}$ century. Such increase in temperature will affect the physiological process and cause faster

*Corresponding author:

N. Manikandan (manilakshmi_144@yahoo.com) 
development and possibly result in more generations in a season [10]. All developmental stages, including eggs, are classically affected by their thermal environment [11], and eggs could respond early, as soon as the embryonic development starts. Survival of brown plant hopper nymphs at 31,35 , and $38^{\circ} \mathrm{C}$ was significantly lower than that at $26^{\circ} \mathrm{C}$ [12]. The potential rate of development in insect population is strongly dependent on temperature and their survival is impaired at temperature extremes [13]. With this background, an experiment was taken up to study the influence of temperature on the survival and development time of rice yellow stem borer.

\section{Materials and Methods}

\subsection{Climate Control Chamber}

Experiments were carried out in Climate Control Chamber (CCC), established at Agro Climate Research Centre, Tamil Nadu Agricultural University, which is situated $11^{\circ} \mathrm{N}$ latitude and $77^{\circ} \mathrm{E}$ longitude and is at an elevation of $427 \mathrm{~m}$ above the mean sea level. Temperature CCC was controlled using fogger and a mist fan. Temperature is recorded by the sensor and this sensor is connected to a data logger. For this investigation, five different constant temperatures $\left(28.3^{\circ} \mathrm{C}, 30.6^{\circ} \mathrm{C}, 32.7^{\circ} \mathrm{C}\right.$, $34.3^{\circ} \mathrm{C}$ and $36^{\circ} \mathrm{C}$, same chamber at different times for different constant temperatures) were maintained during the study period.

\subsection{Insect Culture}

For getting uniform population of $S$. incertulas, mass culturing was done by following method [14]. Primary culture was established by collecting the borer moths during the day with a sweep net in the rice fields or during the night in light traps. The collected moths were placed in vials and were brought to the laboratory, where they were confined in wooden cages. The adult moths were fed with $10 \%$ sucrose solution soaked in cotton wool. Rice seedlings (ADT 43) of 40-50 day old plants were kept in the cage for oviposition. After oviposition, the egg mass deposited by the moths was collected by cutting off the leaf section with eggs. The leaf sections were placed on moist filter paper in petri dishes and stored at room temperature until the end of blackhead stage (about 5 days). The larvae hatched were used for the studies.

\subsection{Development Time}

The newly emerged male and female moths were introduced to insect cages (width- $75 \mathrm{~cm}$, Length $-75 \mathrm{~cm}$, Height-82.5 cm, netted on three side) with 1 month duration of paddy crop under 5 different constant temperatures for egg laying. Date of egg laying, number of eggs and percentage of egg hatch were recorded. From the date of egg laying and egg hatch, incubation period was calculated for different temperature ranges. From the regular observations, duration of the different stages of larva was determined under different temperature ranges. The stems were opened carefully without any damage to observe the pupated larva. Once, the larva pupated, it was kept out of the stem after four days of pupation for easy observation of adult emergence.

\section{Results and Discussion}

The number of eggs laid by YSB increased at higher temperature. At $28.3^{\circ} \mathrm{C}$, the YSB laid 143 eggs. But it was increased to 176.5 eggs at $36.0^{\circ} \mathrm{C}$ with a standard deviation of 6.6 (Table 1). Insect populations from environments with higher temperatures may have higher fecundity and shorter growth stage to increase fitness. It is reported that the incubation period of Scirpophaga incertulas decreases at higher temperature, beginning at $30^{\circ} \mathrm{C}$ and continuing up to $35^{\circ} \mathrm{C}$ [15]. Egg hatching percentage of the YSB decreased at higher temperature and increased at lower temperature. The egg hatching percentage was high $(90.6 \%)$ at $30.6^{\circ} \mathrm{C}$ followed by $28.3^{\circ} \mathrm{C}$. In contrast, only 58.5 per cent of incubated eggs achieved emergence at $36.0^{\circ} \mathrm{C}$ (Table 1). Same trend was reported in Willowsia jacobsoni (Borner) in which more than $90 \%$ of the eggs hatched at temperatures from 16 to $35^{\circ} \mathrm{C}$ but percentage of hatching decreased dramatically from $36^{\circ} \mathrm{C}(36.8 \%)$ to $38^{\circ} \mathrm{C}(20.4 \%)$. Inability to complete the hatching process caused most of the mortality at high temperatures [16].

Development time taken by different stages of the YSB decreased considerably at higher temperature. The incubation period of YSB eggs was 8.5 days at $28.3^{\circ} \mathrm{C}$, whereas it took only 5.75 days at $36^{\circ} \mathrm{C}$ (Table 2). The development time taken by the four larval instars varied significantly with respect to the temperature. For example, the $1^{\text {st }}, 2^{\text {nd }}$, $3^{\text {rd }}$ and $4^{\text {th }}$ instars took $7.25,6.5,7.75$ and 7.25 days, respectively at $28.3^{\circ} \mathrm{C}$ whereas it took $5.25,4.5,6.25$ and 5.5 , respectively at $36^{\circ} \mathrm{C}$. There was difference of 2.5 days in 
pupal period between the lowest and highest incubation temperature as it took 7.5 days at $28.3^{\circ} \mathrm{C}$ and 5.0 days at $36^{\circ} \mathrm{C}$ (Figure 1). Many researchers have reported that the durations of different aphid instars shortened as temperature increased [17-20]. The longevity of the female and male adult was 7.25 and 5.25 days, respectively, but it was 5.75 and 3.75 days, respectively at $36^{\circ} \mathrm{C}$. The above results were in line with the results of [21] who reported that the developmental time was inversely related to temperature.

\section{Conclusion}

It is clear that the number of eggs laid increased at higher incubation temperatures while the hatching percentage was drastically reduced due to the inability of eggs to hatch. The development time taken by YSB decreased considerably at higher incubation temperatures which resulted in more numbers of generations. As the temperature is projected to rise, insects will develop faster and will

Table 1. Total number of eggs laid by YSB and its hatching percentage at different incubation temperatures

\begin{tabular}{lccccc}
\hline Particulars & $28.3^{\circ} \mathrm{C}$ & $30.6^{\circ} \mathrm{C}$ & $32.7^{\circ} \mathrm{C}$ & $34.3^{\circ} \mathrm{C}$ & $36.0^{\circ} \mathrm{C}$ \\
\hline Eggs & $143 \pm 9.9^{\mathrm{d}}$ & $138.8 \pm 11.3^{\mathrm{e}}$ & $148.5 \pm 14.8^{\mathrm{c}}$ & $168 \pm 9.9^{\mathrm{b}}$ & $176.5 \pm 6.61^{\mathrm{a}}$ \\
Hatching (\%) & $89.5^{\mathrm{b}}$ & $90.6^{\mathrm{a}}$ & $85.9^{\mathrm{c}}$ & $70.8^{\mathrm{d}}$ & $58.5^{\mathrm{e}}$ \\
\hline
\end{tabular}

Values are mean of four replications

In a row, means followed by a letter are significantly different at 5\% level of LSD

Table 2. Development time taken by different stages of YSB at different incubation temperatures

\begin{tabular}{lccrrr}
\hline Stage & $\mathbf{2 8 . 3 ^ { \circ } \mathbf { C }}$ & \multicolumn{1}{c}{$\mathbf{3 0 . 6 ^ { \circ }} \mathbf{C}$} & $\mathbf{3 2 . 7 ^ { \circ } \mathbf { C }}$ & \multicolumn{1}{c}{$\mathbf{3 4 . 3 ^ { \circ } \mathbf { C }}$} & \multicolumn{1}{c}{$\mathbf{3 6 . 0 ^ { \circ } \mathbf { C }}$} \\
\hline Egg & $8.50 \pm 0.58^{\mathrm{a}}$ & $7.75 \pm 0.50^{\mathrm{b}}$ & $6.75 \pm 0.50^{\mathrm{c}}$ & $6.25 \pm 0.50^{\mathrm{d}}$ & $5.75 \pm 0.50^{\mathrm{e}}$ \\
1st Instar & $7.25 \pm 0.5^{\mathrm{a}}$ & $6.75 \pm 0.96^{\mathrm{b}}$ & $6.5 \pm 0.58^{\mathrm{c}}$ & $5 \pm 0.82^{\mathrm{d}}$ & $5.25 \pm 0.50^{\mathrm{e}}$ \\
2nd Instar & $6.50 \pm 0.58^{\mathrm{a}}$ & $5.50 \pm 0.58^{\mathrm{b}}$ & $5.50 \pm 0.58^{\mathrm{c}}$ & $5.00 \pm 0.82^{\mathrm{d}}$ & $4.50 \pm 0.58^{\mathrm{e}}$ \\
3rd Instar & $7.75 \pm 0.96^{\mathrm{a}}$ & $7.50 \pm 0.58^{\mathrm{b}}$ & $7.00 \pm 0.82^{\mathrm{c}}$ & $6.75 \pm 0.50^{\mathrm{d}}$ & $6.25 \pm 0.96^{\mathrm{e}}$ \\
4th Instar & $7.25 \pm 0.5^{\mathrm{a}}$ & $7.00 \pm 0.82^{\mathrm{b}}$ & $6.50 \pm 0.58^{\mathrm{c}}$ & $6.25 \pm 0.50^{\mathrm{d}}$ & $5.50 \pm 0.58^{\mathrm{e}}$ \\
Larva & $28.75 \pm 1.26^{\mathrm{a}}$ & $26.75 \pm 0.50^{\mathrm{b}}$ & $25.50 \pm 0.58^{\mathrm{c}}$ & $23.00 \pm 0.82^{\mathrm{d}}$ & $21.50 \pm 0.58^{\mathrm{e}}$ \\
Pupa & $7.50 \pm 0.58^{\mathrm{a}}$ & $7.25 \pm 0.96^{\mathrm{b}}$ & $6.75 \pm 0.96^{\mathrm{c}}$ & $6.25 \pm 0.50^{\mathrm{d}}$ & $5.00 \pm 0.82^{\mathrm{e}}$ \\
Female Longevity & $7.25 \pm 0.96^{\mathrm{a}}$ & $7.00 \pm 0.82^{\mathrm{b}}$ & $6.25 \pm 0.50^{\mathrm{c}}$ & $6.00 \pm 0.0^{\mathrm{d}}$ & $5.75 \pm 0.50^{\mathrm{e}}$ \\
Male Longevity & $5.25 \pm 0.50^{\mathrm{a}}$ & $5.25 \pm 0.50^{\mathrm{b}}$ & $4.75 \pm 0.50^{\mathrm{c}}$ & $4.00 \pm 0.82^{\mathrm{d}}$ & $3.75 \pm 0.50^{\mathrm{e}}$ \\
\hline
\end{tabular}

Values are mean of four replications

In a row, means followed by a letter are significantly different at $5 \%$ level of LSD

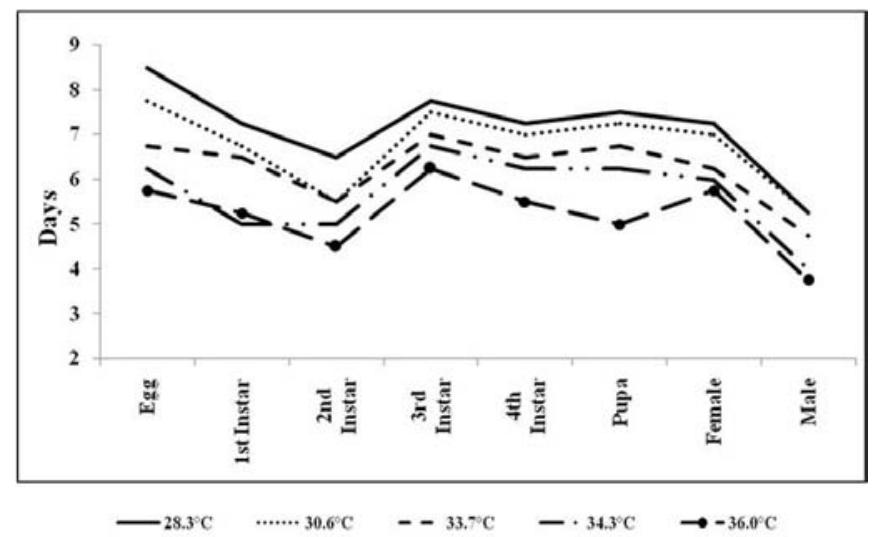

Figure 1. Development time taken by different stages of YSB at different temperature regimes. 
oviposit early leading to earlier population growth than expected.

\section{References}

1. Dhaliwal G S, Jindal V et al. (2010). Insect pest problems and crop losses: changing trends, Indian Journal of Ecology, vol 37(1), 1-7.

2. Saxena R C, and Shrivastava R C (2007). Entomology at a glance, Agrotech Publishing Academy, Udaipur, India, 464.

3. Pathak M D, and Dhaliwal G S (1981). Trends and strategies for rice insect problems in tropical Asia, International Rice Research Institute LosBanos: IRRI research paper series, vol 64, 15.

4. Listinger J A (1979). Major insect-pests of rainfed wetland rice, Tropical Asia International Rice Research Newsletter, vol 4(2), 14-15.

5. Banerjee S N, and Pramanik L M (1967). The lepidopterous stalk borers of rice and their life cycle in the tropics, The major insect pests of the rice plant, Proceedings of a Symposium, 103-124.

6. Pathak M D (1968). Ecology of common insect pests of rice, Annual Review of Entomology, vol 13(1), 257-294.

7. Chelliah A, Benthur J S et al. (1989). Approaches to rice management-achievements and opportunities, Oryzae, vol 26(2), 12-26.

8. Bale J, Masters G et al. (2002). Herbivory in global climate change research: direct effects of rising temperature on insect herbivores, Journal of Global Change Biology, vol 8(1), 1-16.

9. Intergovernmental Panel on Climate Change (IPCC) (2007). Climate change 2001: Third Assessment Report of the Intergovernmental Panel on Climate Change, 809.

10. Hansen M E, Bentz B J et al. (2001). Temperature based model for predicting univoltine brood proportions in spruce beetle (Coleoptera: Scolytidae), Canadian Entomologist, vol 133(6), 827-841.
11. Bonato O, Lurette A et al. (2007). Modelling temperature-dependent bionomics of Bemisiatabaci (Q-biotype), Physiological Entomology, vol 32(1), 50-55.

12. Xiaoping Y, Guorui W et al. (1992). Effect of high temperatures on the survival and fecundity of Brown Plant Hopper (BPH) Nilaparvata lugens Stal, IRRN-International Rics Research Newsletter, vol 17(2), 26.

13. Intergovernmental Panel on Climate Change (IPCC) (2001). Climate change 2007: Fourth Assessment Report of the Intergovernmental Panel on Climate Change, 94.

14. Saxena R C, Medrano F G et al. (1990). Rearing Yellow Stem Borer (YSB) for screening varietal resistance, International Rice Research Newsletter, vol 15(3), 15.

15. Pathak M D, and Khan Z R (1994). Insect pests of rice, IRRI, Philippines, 89.

16. Jose A, Mutt M et al. (1984). Effects of temperature on the embryonic development of Willowsia jacobsoni (Borner) (Collembola: Entomobryidae), Caribbean Journal of Science, vol 20(1-2), 57-66.

17. Komazaki S (1982). Effects of constant temperature on population growth of three aphid species, Toxopteracitricidus (Kirkaldy), Aphis citricola Van Der Goot and Aphis gossypii Glover (Homoptera: Aphididae) on citrus, Applied Entomology and Zoology, vol 17(1), 75-81.

18. Mink A K, and Harrewijn P (1987). Aphids: their biology, natural enemies and control, vol A, Elsevier, Amsterdam, The Netherlands, 450.

19. Hirano K, Honda K I et al. (1996). Effects of temperature on development, longevity and reproduction of the soybean aphid, Aphis glycines (Homoptera: Aphididae), Applied Entomology and Zoology, vol 31(1), 178-180.

20. Wang J J, and Tsai J H (2001). Development, survival and reproduction of black citrus aphid, Toxoptera aurantii(Hemiptera: Aphididae), as a function of temperature, Bulletin of Entomological Research, vol 91(6), 477-487.

21. Tamiru A, Getu E et al. (2011). Effect of temperature and relative humidity on the development and fecundity of Chilopartellus (Swinhoe) (Lepidoptera: Crambidae), Bulletin of Entomological Research, vol 102(1), 9-15. 